\title{
Microchemical variation in juvenile Solea solea otoliths as a powerful tool for studying connectivity in the North Sea
}

\author{
E. L. Cuveliers ${ }^{1, *}$, A. J. Geffen ${ }^{2}$, J. Guelinckx ${ }^{1}$, J. A. M. Raeymaekers ${ }^{1}$, J. Skadal ${ }^{2}$, \\ F. A. M. Volckaert ${ }^{1}$, G. E. Maes ${ }^{1}$ \\ ${ }^{1}$ Katholieke Universiteit Leuven, Laboratory of Animal Diversity and Systematics, Charles Debériotstraat 32, \\ 3000 Leuven, Belgium \\ ${ }^{2}$ University of Bergen, Department of Biology, Box 7803, 5020 Bergen, Norway
}

\begin{abstract}
Estimating connectivity between juvenile and adult fish habitats can provide an important contribution to effective fisheries management, through a better understanding of population resilience to harvesting pressure. Indirect methods for quantifying connectivity, such as geochemical or genetic techniques, allow us to assign adults from various sampling regions to their natal location, provided that natal origin data can be defined. The elemental composition of otoliths from juvenile sole Solea solea collected at 4 sampling locations in the Southern Bight of the North Sea was measured using laser-ablation inductively-coupled plasma mass spectrometry (LA-ICPMS), to determine elemental fingerprints indicative of distinct nursery grounds. Significant differences in elemental composition were detected among the 4 locations, with $\mathrm{Na}, \mathrm{Sr}, \mathrm{Ba}, \mathrm{Mn}$ and $\mathrm{Rb}$ concentrations varying the most between groups. A discriminant model resulted in high assignment proportions of the juvenile fish to their respective nursery grounds with a total jackknife reclassification success of $88 \%$. Even though some interannual variability in otolith chemistry was observed in juveniles from the Scheldt estuary, spatial patterns seemed to dominate. Our results constitute a firm basis for future investigations on nursery area contributions and quality, adult dispersal history and applications of population traceability.
\end{abstract}

KEY WORDS: Connectivity - Juvenile fish - Nursery - Otolith microchemistry - Traceability · Solea solea Resale or republication not permitted without written consent of the publisher

\section{INTRODUCTION}

Understanding population connectivity is an important component of effective fisheries management, because the exchange of individuals among geographically separate groups determines the colonization rate of new habitats, the resilience to harvesting and the success of management measures such as marine protected areas (Thorrold et al. 2001). Furthermore, essential habitats must be identified based on knowledge about the spatial scales of movement of individuals and habitat use of different life history stages to select habitats for conservation (Beck et al. 2001, Fogarty \& Botsford 2007).
Connectivity in marine fish populations can be estimated from a variety of direct and indirect sources. Direct physical tagging is widely applied and such studies can provide insights about movement patterns and habitat range. Nevertheless, most tagging studies focus on adult fish due to the limited feasibility of physical tags in small or juvenile fish (Palumbi 2004, Cowen \& Sponaugle 2009) and may require recapturing the fish, which poses many challenges in an open environment such as the ocean (Thorrold et al. 2002). Indirect methods using genetic markers can also be used to investigate connectivity between populations by calculating the amount of gene flow and the extent of genetic differentiation. Furthermore, genetic methods 
provide insights into the spatio-temporal connectivity on an evolutionary time scale (in the order of hundreds of generations) (Hedgecock et al. 2007). In marine fish, however, the chances of detecting strong genetic structure, applicable to management decisions, are low because even few migrants suffice to prevent detectable differentiation (Hellberg et al. 2002, Hartl \& Clark 2007). Since the 1980s, otolith elemental composition has increasingly been used to describe life histories of fish, study small scale variability in seasonal and within-generation migrations and identify the various environments fish have experienced. The use of trace elements in otoliths is based on the empirical evidence that fish incorporate elements from their environments and that these elements are permanently deposited in their continuously growing otoliths (Campana 1999, Thresher 1999). Consequently, the chemical composition of otoliths differs among fish from different geographical areas and constitutes a powerful multielemental signal reflecting the surrounding physical and chemical environment (Vasconcelos et al. 2007). Juvenile fish that have lived in different coastal environments or estuaries are often characterised by a distinct otolith composition, referred to as the elemental fingerprint. Analysis of otolith composition has been successfully applied in a wide range of flatfish species living in different habitats (De Pontual et al. 2000, Forrester \& Swearer 2002, Gillanders 2002a, Geffen et al. 2003, Brown 2006a, Vasconcelos et al. 2007). Because different nursery areas can be defined by a distinct otolith element signature derived from the composition of juveniles sampled there, adult fish can be assigned to their nursery area by comparing the elemental composition of the central otolith zone, which represents the first year of life, with the specific nursery signature (Thorrold et al. 2001, Brown 2006b, Vasconcelos et al. 2008). Results can provide crucial information on migration distance, mixed-stock analyses of feeding aggregations and the relative importance of different nurseries, estimated as the fraction of successful recruits originating from a specific nursery area (Gillanders 2002a).

Sole Solea solea (Soleidae; Teleostei) is a commercially important flatfish in the northeastern Atlantic Ocean and to a lesser extent in the Mediterranean Sea, but is overexploited throughout most of its range. In the North Sea, sole spawn from early April until August, with a main peak in May, at water temperatures ranging between 8 and $12^{\circ} \mathrm{C}$ (van der Land 1991, Rijnsdorp et al. 1992). There are 5 main sole spawning grounds in the North Sea, namely the inner German Bight, in the eastern English Channel off the Belgian Coast, in the Thames and on the Norfolk Banks (Russel 1976, Rijnsdorp et al. 1992). About $30 \mathrm{~d}$ after hatching, the pelagic larvae metamorphose and settle in shallow marine coastal habitats and estuaries that provide suitable feeding conditions (van der Veer et al. 2001, Amara 2004). The juvenile sole stay in these nursery areas for up to $2 \mathrm{yr}$ before they move offshore and reach maturity from the age of 3 onwards (Pawson 1995, Burt \& Millner 2008). Sole nurseries are situated along the shallow muddy and sandy coasts of the North Sea and in the estuaries. Because estuaries and coastal areas are characterised by a distinct water chemistry compared with the open sea, and because spawning areas are not far from the nursery grounds in the North Sea, the likelihood for successful population assignments using otolith microchemistry is expected to be high for sole, as has been shown elsewhere (e.g. Bay of Biscay, De Pontual et al. 2000; Portuguese coast, Vasconcelos et al. 2007, 2008; Thames, Leakey et al. 2009).

Tagging experiments on sole in the southern North Sea and the Irish Sea (Symonds \& Rogers 1995, Burt \& Millner 2008) indicate that sole undertake relatively short migrations away from the coastal nursery and spawning grounds. Movements are seasonal with mature sole migrating inshore to spawn in spring and moving offshore in winter. In the North Sea, mainly northward offshore movements have been observed, which may be associated with the northward residual current. Few sole migrate from the Belgian and Dutch coasts into the Thames area, possibly pointing to a stable separation between populations. Within the eastern English Channel strong site fidelity has been observed (Burt \& Millner 2008).

The entire sole stock in the North Sea region (ICES Area IVc) is currently managed as a single unit, potentially leading to over-harvesting of unrecognized populations. If the current management unit consists of several sub-units, fishing pressure forms a threat to the maintenance of intra-specific (phenotypic and genetic) diversity at the species and population levels (Frank \& Brickman 2001, Secor et al. 2009). A thorough and integrated reassessment of the spatial and temporal scale of population connectivity using current methodologies is urgently needed to avoid the extirpation of small populations. Although various studies have analysed the microchemical fingerprint signal in sole, all studies focused on a relatively small area, while almost nothing is known about the connectivity of sole at the North Sea scale or between local populations across the English Channel, or about the relative contributions of the neighbouring nursery grounds.

The main objectives of the present study are (1) to characterise juvenile otolith microchemical fingerprints from 4 known nursery areas for sole in the North Sea (along coasts and on opposite sides of the southern North Sea) and (2) to assess the discriminative power of sole microchemistry signatures of nurseries located in the Southern Bight of the North Sea. Hence, we aim 
at testing the applicability of otolith microchemistry to trace back to the nursery grounds of origin of adult soles at a larger geographical scale, such as in the dynamic North Sea Basin.

\section{MATERIALS AND METHODS}

Sampling. Juvenile fish (0-group and 1-group) were collected at 4 sampling sites in the autumn of 2006 and/or 2007 as follows: near the mouth of the Thames (THA07), off the Humber estuary (Lincolnshire area, LINC07), in the Wadden Sea (near Texel, TEX06) and in the Scheldt estuary (near Zandvliet, ZAN06 and ZAN07) (Fig. 1). We selected these 4 sampling locations because they are adjacent to known spawning grounds in the Thames, Norfolk Banks, German Bight and Belgian coast and represent some of the most important nursery areas with high densities of juvenile flatfish (Rijnsdorp et al. 1992, Hamerlynck et al. 1993, Rogers et al. 1998, Beyst et al. 1999, Hostens 2000, van der Veer et al. 2001, Vinagre et al. 2008a).

Samples were obtained from standard surveys using a beam trawl, except for the Scheldt estuary, where samples were collected in both 2006 and 2007 with fyke nets placed on an intertidal mud flat (Table 1). The geographical distance between the sampling sites ranged from 193 to $293 \mathrm{~km}$. Data on abiotic variables were obtained from databases of the Flemish Environment Agency (VMM), from the Dutch Ministry of Transport, Public Works and Water Management (available at: www.waterbase.nl) or were measured during the surveys. Fish were stored immediately at $-20^{\circ} \mathrm{C}$ and further measurements (total length, weight) and otolith extractions (sagittae) were performed in the laboratory. From each location, the otoliths of 20 to $40 \mathrm{fish}<20 \mathrm{~cm}$ in length (0-group and 1-group) were selected for otolith microchemistry analysis (Table 1).

Otolith preparation. The left sagitta was used for analysis, except when only the right sagitta could be retrieved. To remove any surface contamination, the otoliths were cleaned using a standard decontamina- tion protocol for otoliths (Otolith Research Laboratory, Bedford Institute of Oceanography, Canada). Only analytical grade chemicals and equipment made of Teflon, polyethylene or polypropylene were used. Otoliths were cleaned of any adhering tissues, placed in labelled vials, covered with ultrapure water and sonicated for $5 \mathrm{~min}$. Otoliths were scrubbed with a nylon brush, rinsed 3 times with ultrapure water, placed back in the vials and sonicated for another $3 \mathrm{~min}$. After cleaning, the otoliths were dried within the vial. The dry otoliths were weighed to the nearest $0.005 \mathrm{mg}$ and then stored in freshly acid-washed vials awaiting further preparation. Up to 30 juvenile sole otoliths were mounted on a single geology slide in epoxy resin, lined in a row with their proximal side facing up. They were ground by hand using a series of grinding papers and polished with diamond paste $(3,1$ and $0.25 \mu \mathrm{m}$ in that order) until the edge material could be sampled. Spec-

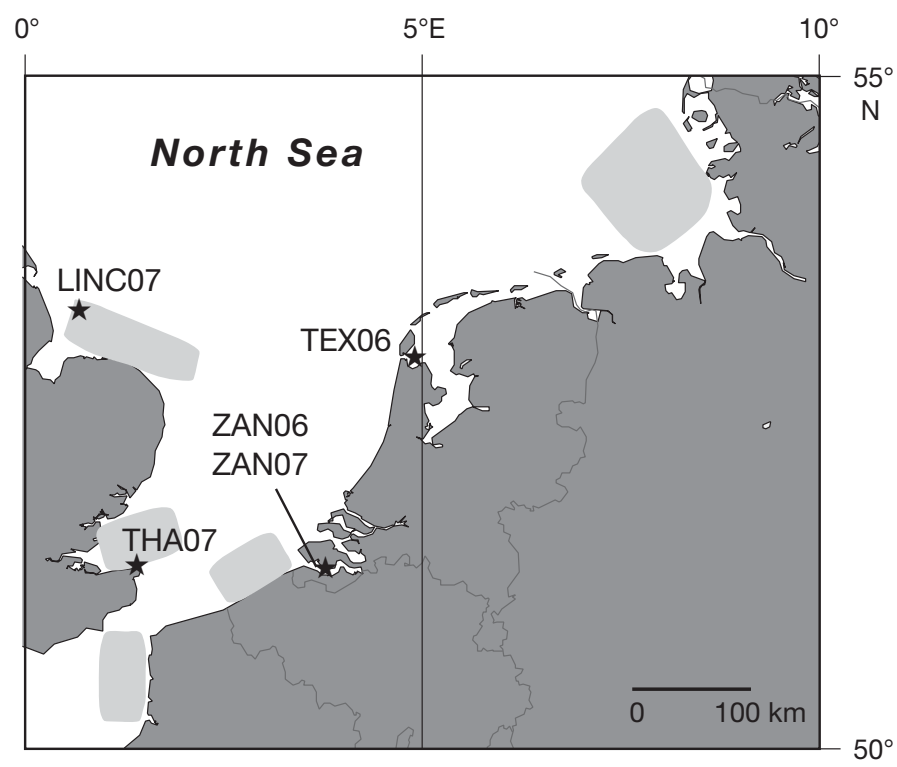

Fig. 1. Solea solea. Study area showing sampling sites: Lincolnshire near Humber estuary (LINC07), Thames (THA07), Wadden Sea near Texel (TEX06) and Scheldt estuary near Zandvliet (ZAN06, ZAN07). Numbers in the location code indicate sampling year and the shaded areas indicate sole spawning grounds

Table 1. Solea solea. Overview of sampling sites, sampling code, latitude and longitude coordinates of sampling site, sampling year, water temperature $\left(\mathrm{T},{ }^{\circ} \mathrm{C}\right)$, salinity $(\mathrm{Sal})$, number of samples analysed $(\mathrm{N})$, mean $\pm \mathrm{SD}$ fish total length $(\mathrm{TL}, \mathrm{cm})$, mean $\pm \mathrm{SD}$ otolith weight (OW, mg)

\begin{tabular}{|lcccccrcr}
\hline Sampling site & \multirow{2}{*}{ Sampling code } & Coordinates & Year & T & Sal & N & TL (cm) & OW (mg) \\
\hline Zandvliet (Scheldt estuary) & ZAN06 & $51^{\circ} 24^{\prime} 1^{\prime \prime} \mathrm{N}, 4^{\circ} 11^{\prime} 40^{\prime \prime} \mathrm{E}$ & 2006 & 18.6 & 11 & 36 & $9.9 \pm 0.59$ & $1.58 \pm 0.20$ \\
Zandvliet (Scheldt estuary) & ZAN07 & $51^{\circ} 24^{\prime} 1^{\prime \prime} \mathrm{N}, 4^{\circ} 11^{\prime} 40^{\prime \prime} \mathrm{E}$ & 2007 & 16 & 10 & 30 & $11.2 \pm 0.85$ & $2.17 \pm 0.35$ \\
Thames & THA07 & $51^{\circ} 25^{\prime} 14^{\prime \prime} \mathrm{N}, 1^{\circ} 23^{\prime} 49^{\prime \prime} \mathrm{E}$ & 2007 & 17.7 & 34.2 & 35 & $10.1 \pm 1.19$ & $1.55 \pm 0.29$ \\
Texel (Wadden Sea) & TEX06 & $52^{\circ} 57^{\prime} 46^{\prime \prime} \mathrm{N}, 4^{\circ} 57^{\prime} 12^{\prime \prime} \mathrm{E}$ & 2006 & $18^{\mathrm{a}}$ & $28.7^{\mathrm{a}}$ & 28 & $9.8 \pm 0.90$ & $1.16 \pm 0.19$ \\
Lincolnshire (Humber estuary) & LINC07 & $53^{\circ} 19^{\prime} 96^{\prime \prime} \mathrm{N}, 0^{\circ} 25^{\prime} 63^{\prime \prime} \mathrm{E}$ & 2007 & 16.4 & 32.2 & 23 & $17.2 \pm 2.29$ & $5.99 \pm 1.83$
\end{tabular}

aData were not collected but estimated from monthly means (source 'Waterbase', available at: www.waterbase.nl) 
imens from different locations were randomised on each slide (to avoid preparation artefacts). Finally, to remove any remaining surface contamination, each slide was sonicated for $10 \mathrm{~min}$ in milliQ water and dried under a laminar flow cabinet.

Mass spectrometry measurement. The chemical composition of the nursery ground portion of the juvenile sole otoliths was determined by laser-ablation inductively-coupled plasma mass spectrometry (LAICPMS) analyses using a Finnigan ELEMENT 2 ICPMS (Thermo Electron Corporation) coupled to a UP266 MACRO laser system (New Wave Research). Laser conditions $(10 \mathrm{~Hz}$ repetition rate, $50 \mathrm{~ms}$ dwell time, medium resolution) induced a crater of $60 \mu$ m diameter at the outermost part of the otolith. Measurements were performed on the otolith edge to ensure that the analysed material was laid down just before capturing the fish at the nursery ground. For all the otoliths, the following isotopes were measured: ${ }^{7} \mathrm{Li},{ }^{23} \mathrm{Na},{ }^{24} \mathrm{Mg}$, ${ }^{25} \mathrm{Mg},{ }^{43} \mathrm{Ca},{ }^{55} \mathrm{Mn},{ }^{59} \mathrm{Co},{ }^{63} \mathrm{Cu},{ }^{66} \mathrm{Zn},{ }^{85} \mathrm{Rb},{ }^{86} \mathrm{Sr},{ }^{88} \mathrm{Sr},{ }^{137} \mathrm{Ba}$, ${ }^{138} \mathrm{Ba}$ and ${ }^{208} \mathrm{~Pb}$. For the elements $\mathrm{Mg}$, Sr and $\mathrm{Ba}, 2$ isotopes were initially quantified to test for possible mass interference. The isotopes with the least interference were selected for statistical analyses: ${ }^{24} \mathrm{Mg},{ }^{86} \mathrm{Sr}$ and ${ }^{138} \mathrm{Ba}$. Two reference materials (BCR-2 carbonate powder and NIES CRM no. 22 fish otolith powder [National Institute for Environmental Studies, Japan]) were pressed into pellets for laser ablation. These were included as reference standards with National Institute of Standards and Technology (NIST) 610 glass as calibration standards and were measured between every 15 spots for calibrations. Data below the limits of detection (LOD) were set to the limit of detection. Estimates of precision ( $\%$ relative standard deviation [RSD]) based on the repeated analyses of the NIST 610 standard were determined for each element as follows: ${ }^{7} \mathrm{Li}=3.45 \%,{ }^{23} \mathrm{Na}=2.37 \%,{ }^{24} \mathrm{Mg}=3.02 \%,{ }^{55} \mathrm{Mn}=1.68 \%$ ， ${ }^{59} \mathrm{Co}=2.17 \%,{ }^{63} \mathrm{Cu}=2.70 \%,{ }^{66} \mathrm{Zn}=6.61 \%,{ }^{85} \mathrm{Rb}=2.65 \%$, ${ }^{86} \mathrm{Sr}=3.03 \%,{ }^{138} \mathrm{Ba}=3.64 \%$ and ${ }^{208} \mathrm{~Pb}=3.85 \%$.

Data analysis. Counts per second were processed using the signal integration software GLITTER (GEMOC, Macquarie University) with NIST 610 selected as a standard and ${ }^{43} \mathrm{Ca}$ as internal standard. Values were expressed as element concentrations $\left(\mu \mathrm{g} \mathrm{g}{ }^{-1}\right)$, normalised to ${ }^{43} \mathrm{Ca}$ (Longerich et al. 1996). The minimum detection limit at the $99 \%$ confidence level was calculated by the GLITTER software using an algorithm developed by Longerich et al. (1996) (LOD $=2.3 \times \sqrt{2 \mathrm{~B}}$ with $B$ representing the total number of counts in the background interval) (Van Achterberg et al. 2001). Otolith element concentrations were $\log _{10}$ transformed to achieve a normal data distribution and homogeneity of variances between groups. Since many aspects of growth can influence elemental incorporation, the variation in $\log _{10}$-transformed total fish length between sampling sites was examined using a 1-way ANOVA. Although total fish length differed significantly between groups (ANOVA: $F_{4,140}=155.1$, p < 0.0001), with mainly the sample LINC07 consisting of larger fish (Table 1), no significant effect of the covariate length on variation in otolith composition was visible (analysis of covariance [ANCOVA]: $F_{10,130}=1.3, p=0.23$ ). Variation in otolith composition within and between sampling sites was thus evaluated and quantified using a multiple analysis of variance (MANOVA). Post hoc comparisons using Tukey's Honestly Significant Difference tests were subsequently applied, to pinpoint the significantly different nurseries.

Forward stepwise linear discriminant function analysis (LDFA) was used to discriminate between nurseries, including only elements in the model that contribute most to the discrimination. The functions generated were then used to classify fish according to nursery ground. A cross-validation algorithm using a jackknife technique was applied to determine the classification accuracy. A randomisation technique was used to test the significance of the observed reclassification success compared with that expected by chance (White \& Ruttenberg 2007). Initially, all samples (THA07, LINC07, TEX06, ZAN06 and ZAN07) were used to build the discriminant functions and the jackknife reclassification success was evaluated. In a second analysis, 4 geographically separated samples, THA07, LINC07, TEX06 and ZAN06, were used for the calculation of the discriminant functions, while the omitted ZAN07 sample was used as a test group. The latter model made it possible to assess the influence of annual variation in otolith fingerprints on the spatial discrimination success of juvenile soles. Additionally, inter-annual variation in each element was tested using the consecutive samples from Zandvliet (2006, 2007 ) with a pairwise $t$-test for independent samples. Statistical analyses were performed with the software STATISTICA 8.0 (StatSoft, 2008) and SAS v.9.1 (SAS Institute); significance level used for all tests was $\alpha<0.05$.

\section{RESULTS}

Ten elements ( $\mathrm{Na}, \mathrm{Mg}, \mathrm{Mn}, \mathrm{Co}, \mathrm{Cu}, \mathrm{Zn}, \mathrm{Rb}, \mathrm{Sr}, \mathrm{Ba}$, $\mathrm{Pb}$ ) were regularly detected at all sites and thus included in the statistical analyses. The mean percentage of data below the LOD was $\leq 10 \%$ for all elements, except for $\mathrm{Li}(30 \%), \mathrm{Cu}(11 \%)$ and $\mathrm{Pb}(25 \%)$. For the element Li the percentage of data below the LOD was especially high $(60 \%)$ for the samples from LINC07 compared with that from the other locations. Therefore, Li was not included in the statistical analyses. The most abundant trace elements (concentration, 
Table 2. Solea solea. Mean \pm SD elemental concentrations of otolith edges in $\mu \mathrm{g} \mathrm{g}^{-1}$, mean limits of detection (LOD) and percentage of data below the limits of detection ( $\%<$ LOD) for all elements

\begin{tabular}{|lccc|}
\hline Element & Concentration & LOD & $\%<$ LOD \\
\hline $\mathrm{Li}$ & $0.9 \pm 1.36$ & 0.068 & 30 \\
$\mathrm{Na}$ & $3103.2 \pm 361.50$ & 0.107 & 0 \\
$\mathrm{Mg}$ & $48.99 \pm 9.74$ & 0.016 & 0 \\
$\mathrm{Mn}$ & $14.1 \pm 9.62$ & 0.011 & 0 \\
$\mathrm{Co}$ & $0.8 \pm 0.65$ & 0.016 & 9 \\
$\mathrm{Cu}$ & $0.3 \pm 0.22$ & 0.006 & 11 \\
$\mathrm{Zn}$ & $0.6 \pm 0.53$ & 0.014 & 10 \\
$\mathrm{Rb}$ & $0.1 \pm 0.11$ & 0.001 & 3 \\
$\mathrm{Sr}$ & $1627.6 \pm 328.19$ & 0.041 & 0 \\
$\mathrm{Ba}$ & $2.9 \pm 2.31$ & 0.001 & 0 \\
$\mathrm{~Pb}$ & $0.03 \pm 0.05$ & 0.001 & 25 \\
\hline
\end{tabular}

$\left.<100 \mu \mathrm{g} \mathrm{g}^{-1}\right)$ were $\mathrm{Mg}\left(49 \mu \mathrm{g} \mathrm{g}^{-1}\right), \mathrm{Mn}\left(14 \mu \mathrm{g} \mathrm{g}^{-1}\right)$ and Ba $\left(3 \mu \mathrm{g} \mathrm{g}^{-1}\right)$ (Table 2).

Multi-elemental fingerprints differed significantly among sampling locations (MANOVA: $F_{40,498}=30.1$, $\mathrm{p}<0.0001$ ). ANOVA revealed significant differences in elemental concentration between the sampling sites for 8 of the 10 elements analysed (Table 3). Post hoc Tukey's test results indicated that in most cases, 4 to 6 of the elements differed significantly between 2 locations. $\mathrm{Ba}, \mathrm{Na}$ and $\mathrm{Mg}$ differed among several sampling locations (Fig. 2). The Ba concentration was lower in fish from the English coast compared with the samples from the Wadden Sea and Scheldt estuary (Fig. 2). High Mn concentrations were measured in the samples from Texel, which were also characterised by high $\mathrm{Mg}$ concentrations. Samples from Zandvliet in 2006 showed high concentrations of $\mathrm{Cu}, \mathrm{Rb}$ and $\mathrm{Ba}$. Sr concentration was lowest in Zandvliet $\left(1256 \mathrm{\mu g} \mathrm{g}^{-1}\right)$ and highest in the samples from Lincolnshire $\left(2098 \mathrm{\mu g} \mathrm{g}^{-1}\right)$.

Among the 10 elements included in the stepwise analysis, 6 elements were entered into the model $(\mathrm{Mn}$, $\mathrm{Ba}, \mathrm{Sr}, \mathrm{Rb}, \mathrm{Na}$ and $\mathrm{Mg}$ ) with $\mathrm{Mn}, \mathrm{Ba}$ and $\mathrm{Sr}$ as the most

Table 3. Solea solea. Results of univariate ANOVA comparing the elemental concentration of otoliths between sampling locations. Significant $p$-values are in bold text; $\mathrm{df}=4,140$

\begin{tabular}{|lrrc|}
\hline Element & Adjusted $\mathrm{R}^{2}$ & $F$ & $\mathrm{p}$ \\
\hline $\mathrm{Na}$ & 0.384 & 23.403 & $\mathbf{< 0 . 0 0 0 1}$ \\
$\mathrm{Mg}$ & 0.613 & 57.961 & $\mathbf{< 0 . 0 0 0 1}$ \\
$\mathrm{Mn}$ & 0.785 & 132.126 & $\mathbf{< 0 . 0 0 0 1}$ \\
$\mathrm{Co}$ & 0.024 & 1.874 & 0.118 \\
$\mathrm{Cu}$ & 0.045 & 2.712 & $\mathbf{0 . 0 3 2}$ \\
$\mathrm{Zn}$ & 0.014 & 1.529 & 0.197 \\
$\mathrm{Rb}$ & 0.372 & 22.329 & $\mathbf{< . 0 0 0 1}$ \\
$\mathrm{Sr}$ & 0.664 & 72.154 & $\mathbf{< 0 . 0 0 0 1}$ \\
$\mathrm{Ba}$ & 0.752 & 110.225 & $\mathbf{< 0 . 0 0 0 1}$ \\
$\mathrm{Pb}$ & 0.079 & 4.075 & $\mathbf{0 . 0 0 4}$ \\
\hline
\end{tabular}

important. Overall jackknife reclassification success was $88 \%$, which was significantly higher than the $20 \%$ expected by chance $(\mathrm{p}<0.0001)$. The highest classification accuracy $(100 \%)$ was obtained for the individuals from THA07, while most classification errors were associated with the samples of ZAN06 (Fig. 3). Seven fish from ZAN06 were assigned to the correct location but to a different year (2007), 2 were assigned to THA07 and 1 to LINC07. A canonical analysis identified 3 discrete groups of fish differing significantly in their fingerprint pattern: the first group mainly contained the samples from Lincolnshire and Thames, the second group consisted of the samples from Zandvliet (both years) and the third group contained all samples from Texel (Fig. 4). The first discriminant function, which was mainly determined by $\mathrm{Ba}, \mathrm{Mn}$ and $\mathrm{Mg}$ (in growing order of importance), separated these 3 groups and to some extent also the samples from the Thames from those of Lincolnshire. The second discriminant function was mainly determined by $\mathrm{Mn}$ and $\mathrm{Sr}$ and to a lesser extent by Mg. Root 1 and root 2 together explained $85 \%$ of the variation.

Finally, to test the temporal stability of our fingerprinting approach, the element concentrations for fish sampled in 2006 and 2007 near Zandvliet were compared using a $t$-test for independent samples. Significant differences were found between the 2 years for 6 of the 10 elements: $\mathrm{Na}\left(t_{64}=6.0, \mathrm{p}<0.0001\right), \mathrm{Mg}\left(t_{64}=\right.$ $2.12, \mathrm{p}=0.03), \mathrm{Cu}\left(t_{64}=2.08, \mathrm{p}=0.04\right), \mathrm{Rb}\left(t_{64}=6.39\right.$, $\mathrm{p}<0.0001), \mathrm{Sr}\left(t_{64}=8.45, \mathrm{p}<0.0001\right)$ and $\mathrm{Pb}\left(t_{64}=2.59\right.$, $p=0.01$ ). Higher levels of these elements were observed in 2006 compared with 2007. Despite these temporal differences, the classification model remained powerful when using temporal samples of ZAN07 as a test group; all individuals were assigned to ZAN06, with high probabilities for all samples (probabilities $\geq 0.97$ to 1.00 ), suggesting that the temporal variation might be negligible compared with the spatial effect.

\section{DISCUSSION}

The discrimination power of otolith microchemistry to define and trace back biological populations is highly dependent on local physico-chemical conditions and on the degree of larval dispersal away from adult spawning habitats. The present study applied otolith microchemistry as a reliable tool for studies of connectivity of Solea solea over a wide spatial scale along the coasts of the North Sea and on opposite sides of the southern North Sea. The main result was the high assignment proportion to all 4 nursery areas, pointing to the spatial differences in juvenile otolith fingerprints. 

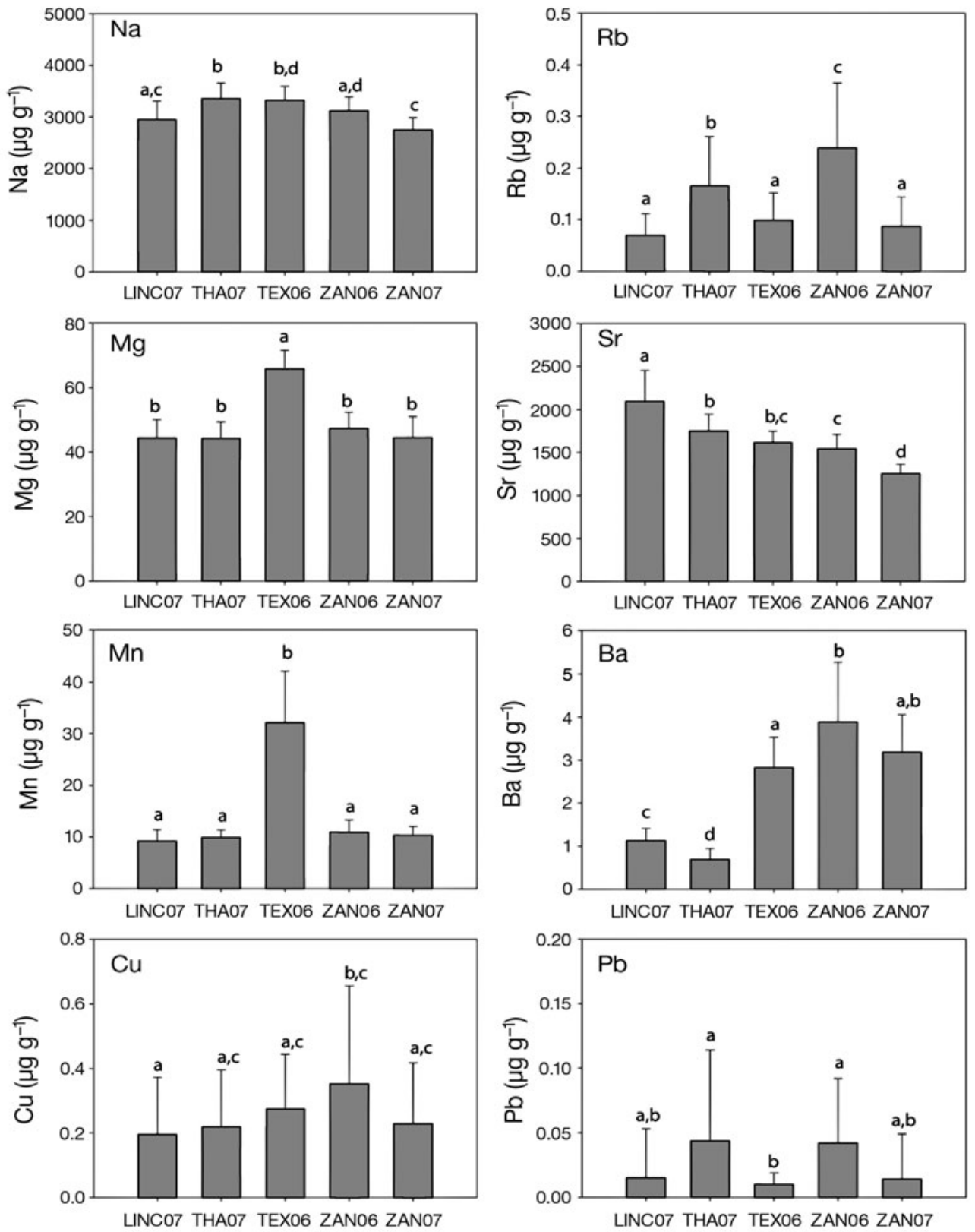

Fig. 2. Solea solea. Mean + SD elemental concentrations of the 8 elements in otolith edges that differed significantly among the sampling locations (see Table 1 for location codes). Bars labelled with different lowercase letters are statistically different from each other (post hoc multiple comparison with Tukey's HSD test)

The elemental concentrations were comparable with published studies in sole and other marine fishes, although the values for $\mathrm{Zn}$ and $\mathrm{Cu}$ were somewhat low (Campana 1999, De Pontual et al. 2000, Vasconcelos et al. 2007). Significant differences in elemental composition between the sampling sites were found for 8 of the 10 elements analysed. Sr concentration was lowest in Zandvliet and highest in the samples from Lincolnshire. Given the strong relationship between $\mathrm{Sr}$ and salinity, this was expected as Zandvliet is situated in the brackish part of the Scheldt estuary where salinity is much lower than it is offshore from Lincolnshire (Limburg 1995, Campana 1999, Secor \& Rooker 2000). Otoliths from the Scheldt were also characterised by higher Ba concentrations. This elevated Ba signal in estuarine, low salinity nursery areas compared with that in coastal areas has been observed in other fish species (Hamer et al. 2006, Leakey et al. 2009). Sources of ambient Ba include terrestrial runoff, groundwater, pollution and remobilisation from sediments (Hamer et 


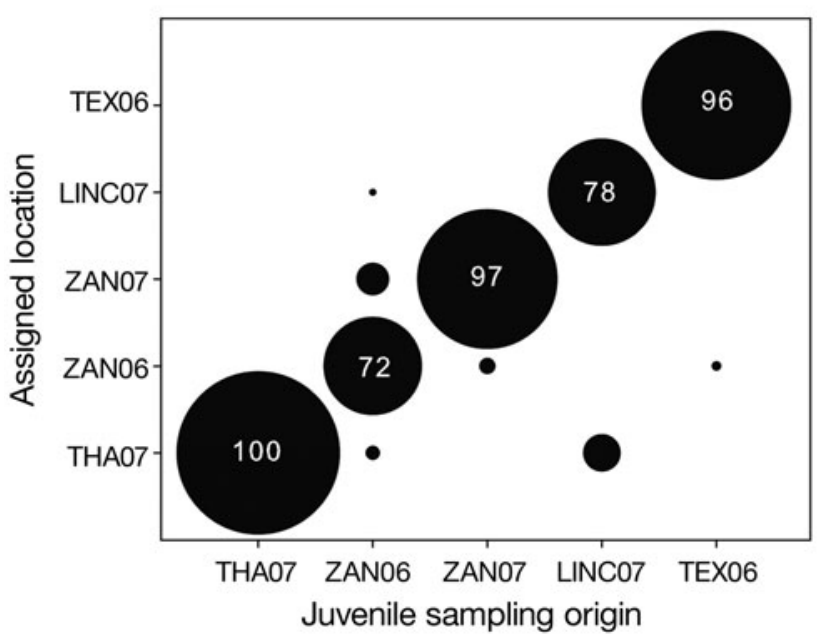

Fig. 3. Solea solea. Allocation of juvenile fish to the sampling groups based on linear discriminant function analysis using the elements $\mathrm{Na}, \mathrm{Mg}, \mathrm{Mn}, \mathrm{Rb}, \mathrm{Sr}$ and $\mathrm{Ba}$. Circle size is scaled relative to the jackknife reclassification success, which is shown (\%) within the larger circles

al. 2006). $\mathrm{Cu}$ and $\mathrm{Pb}$ values were also relatively high in the fish from the Scheldt. The Scheldt Basin is a highly industrialized area with a history of heavy metal pollution, especially for the elements $\mathrm{Cu}, \mathrm{Pb}, \mathrm{Cd}$ and $\mathrm{Zn}$ (Baeyens 1997, Zwolsman 1999, Baeyens et al. 2005). The high Mn concentrations measured in the samples from Texel may be the result of the enrichment of the Wadden Sea in both dissolved and particulate Mn compared with the German Bight or the North Atlantic Ocean. Especially in summer, Mn concentrations reach

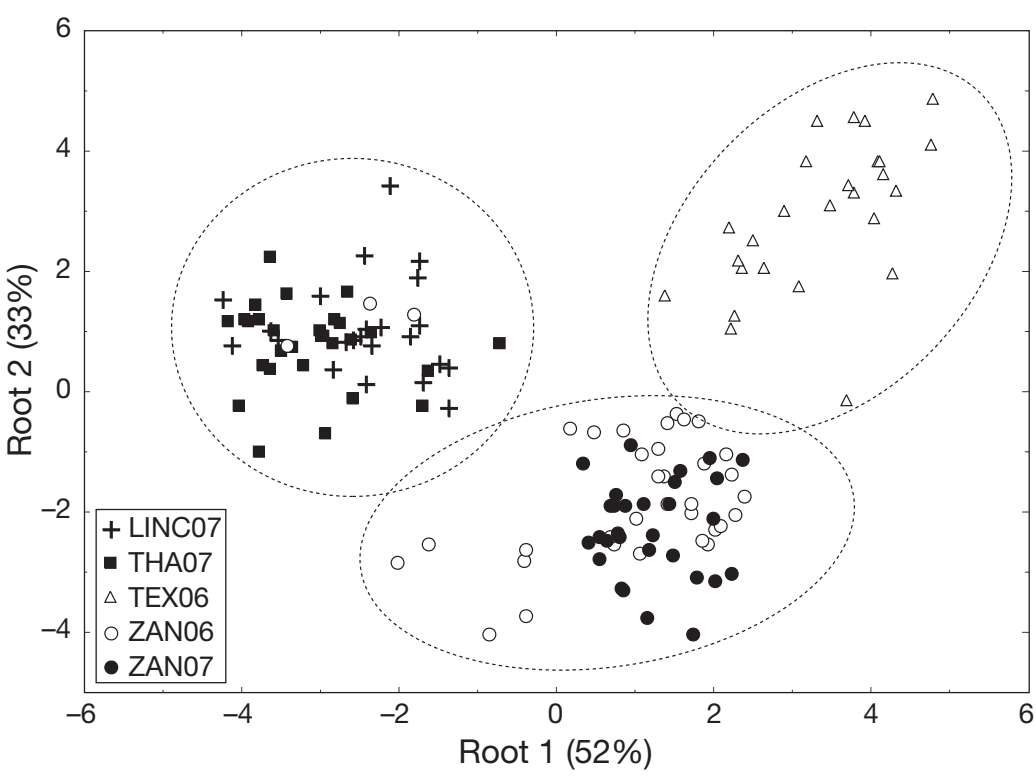

Fig. 4. Solea solea. Canonical correlation analysis of differences in otolith fingerprints for sole. Three main groups are indicated. Both axes explained $85 \%$ of the variation between groups values 10 times higher than in winter due to the increased microbial activity and reducing conditions in the tidal flat sediments (Dellwig et al. 2007).

Trace elemental composition of sole otoliths are appropriate natural tags of these nursery areas in the North Sea; based on 6 of the 10 elements measured ( $\mathrm{Mn}, \mathrm{Ba}, \mathrm{Sr}, \mathrm{Rb}, \mathrm{Na}$ and $\mathrm{Mg}$ ), $88 \%$ of the juvenile sole were correctly assigned to their site of origin. Microchemical variation was higher between samples on opposite sides of the southern North Sea than between samples along the same coastline. Both English sites (Thames and Humber) clustered together and differed more from the samples of Zandvliet and Texel. Although sole from different geographical locations and latitudes differ in life history traits and biological features, our results agree with otolith microchemistry studies on sole carried out in other systems, such as the Bay of Biscay (De Pontual et al. 2000), the Portuguese coast (Vasconcelos et al. 2007) and the Thames (Leakey et al. 2009). De Pontual et al. (2000) showed that spatial discrimination based on otolith microchemistry was possible for juvenile sole in 2 estuaries in the Bay of Biscay, separated by a distance of about $200 \mathrm{~km}$. A relatively high classification success (70\%) has been observed for juvenile sole caught in 8 estuarine nursery areas along the Portuguese coast (Vasconcelos et al. 2007). Finally, Leakey et al. (2009) observed differences in sole elemental signature between estuarine and coastal habitats in the Thames estuary.

In a highly dynamic system such as the North Sea (Otto et al. 1990, Grioche et al. 2001), connectivity between populations in marine species with a pelagic larval phase is expected to be high. Prevailing currents may potentially transport larvae over long distances (Caley et al. 1996). Nevertheless, coastal marine populations may not be as open as previously thought and the level of connectivity might be overestimated (Cowen et al. 2000, Cowen \& Sponaugle 2009). Several factors increase the likelihood for a certain level of discreteness in Solea solea. Populations of sole have been known to show a lower dispersal capacity than that observed in other flatfishes (Rijnsdorp et al. 1992, van der Veer et al. 2000, Grioche et al. 2001), which increases the likelihood for successful population assignments based on otolith microchemistry. Unlike the Bay of Biscay, where adults spawn offshore, in the North Sea spawning takes place in shallow coastal areas and the nurseries are found nearby, along the shallow coasts and in the estuaries. Past 
studies on sole larval distribution suggested that larvae reach the nursery grounds through selective tidal transport (Amara et al. 2000, Grioche et al. 2001). Spawning behaviour of adult sole appears to be linked to hydrodynamics; they spawn where the probability of larvae reaching the nurseries is highest (Grioche et al. 2001). Previous studies on sole using other markers have also suggested a limited juvenile dispersal. Stable isotopes pointed to high site fidelity in 0-group juveniles, but an increased mobility in 1-group sole in Portugal (Vinagre et al. 2008b). Low mobility of young sole after settlement was also shown in the Thames estuary based on the consistent relationships between stable isotope signals of juvenile sole and their prey (Leakey et al. 2008). Tagging studies confirmed a similar pattern of limited movement of juveniles and site fidelity (Burt \& Millner 2008). The low mobility during the juvenile period explains the success of otolith elemental composition from the area of the otolith formed during the juvenile stage as a tag of nursery grounds.

The observed spatial differences between sole nurseries result most probably from a combination of environmental, biological and ontogenetic factors. The North Sea receives the runoff from many large estuaries and rivers. Estuaries are often exposed to a range of anthropogenic pressures (e.g. dredging, sewage input and domestic and industrial effluents) and are also characterised by differences in temperature regime, hydrodynamics, geology, weathering rates and river flow. All these factors lead to different ambient elemental concentrations among locations and ultimately in the observed differences in otolith composition (Thorrold et al. 2007). Given the positioning of our sampling sites, all in the vicinity of an estuary or river, it was expected that the chemical composition of the otoliths would differ among juvenile sole. Ontogenetic and physiological effects are known to influence otolith composition (Thresher 1999, De Pontual et al. 2003). This was observed in Solea solea where a decrease in the $\mathrm{Sr}$ Ca ratio has been linked to high growth rates during metamorphosis (De Pontual et al. 2003). Additionally, a relationship between reproductive status and otolith composition was observed for other species (Thresher 1999). Factors such as temperature variation, ontogeny and stress might thus play a role in the spatial variation, indicating the need for strong background knowledge when performing such studies. In our system, water temperatures were similar between all sites and thus unlikely to be the major cause of the observed Sr variation. Although the soles caught near the Humber consisted mostly of 1-group fish compared with the other sites where only 0-group fish were caught, all fish belonged to the same ontogenetic stage (i.e. immature juvenile fish). Consequently, this age difference might only represent a small, if any, contribution to the observed variation in microchemistry. Overall, otolith fingerprints show great applicability as natural tags of migration history, although further investigations are needed to unveil the complex mechanism behind observed microchemical differences (Gillanders \& Kingsford 2000, Thorrold et al. 2001).

Knowledge on the temporal stability of the geographic variation in fish otoliths is essential for reconstructing individual migration histories. In marine fish, interannual differences in otolith chemistry have been observed, potentially confounding spatial differences. In some cases temporal variability was high, but in other cases spatial trends were similar among cohorts (Gillanders 2002b, Patterson et al. 2008, Schaffler \& Winkelman 2008). Here, the elemental fingerprints of sole caught in the Scheldt estuary were significantly different between years. The discriminant analysis, however, indicated that the spatial signal was stable and more important than the temporal differences. Ideally, a standardised library of elemental fingerprints should be established over time for each estuary (Gillanders 2002b). In reality this information is often lacking and the subsequent assignment of adults to their nursery of origin should be done with care. If temporal variation is obvious, assignment should only be done for year classes where a juvenile signature has been identified. Although our study did not include all potential nursery areas for sole, our results show great promise for the use of otoliths as natural tags of North Sea nurseries. Future assignment and full connectivity studies should increase the number of nurseries, include more temporal samples and use appropriate statistical tools (such as individual based Bayesian MCMC algorithms) without a priori population information when not all source populations are sampled (White et al. 2008).

Certain elements, especially heavy metals present in trace concentrations, may still represent valuable tracers of distinct environments even though they might be difficult to detect (Arslan \& Secor 2005). Therefore, it is important to develop a robust method for including these values in statistical analyses and discriminant models. One method proposed is to replace values below the LODs with estimated values, derived from maximum likelihood modeling (Helsel \& Hirsch 2002). Another method would be to code such values as present or absent, and treat these elements as categorical values within multivariate analyses, as established in community ecology studies.

This study was the first step towards assessing patterns of connectivity and the importance of nursery habitats for sole in the North Sea. The next step will be to collect adult otoliths from various regions and attempt to match the chemical signatures of the juve- 
nile portion of their otolith with the atlas generated from juveniles caught on the nursery grounds. Combining information on the relative abundance of sole on each nursery ground with the proportion of adults that show a given nursery signature could quantify the relative importance of particular nurseries for population replenishment. Such information is important for sustainable fisheries management.

Acknowledgements. Research has been funded by the European Community's Seventh Framework Programme under contract no. KBBE-212399 (FishPopTrace). The authors thank L. Bolle (IMARES), S. Geldof (Katholieke Universiteit Leuven), scientists from ILVO and the crew of RV 'Belgica' and RV 'Zeeleeuw' for their help at sea. Many thanks to O. Tumyr and J. Kosler (Centre of Geobiology, University of Bergen) for their help with the operation of the laser and ICPMS. Acknowledgements to the BeNCoRe network and Research Foundation-Flanders (FWO-Vlaanderen) for a travel grant. E.C. acknowledges a PhD grant from the Institute for the Promotion of Innovation through Science and Technology in Flanders (IWT-Vlaanderen). G.E.M. is a post-doctoral researcher funded by the Research Foundation-Flanders (FWOVlaanderen). We acknowledge the helpful comments of 4 anonymous reviewers.

\section{LITERATURE CITED}

Amara R (2004) 0-group flatfish growth conditions on a nursery ground (Bay of Canche, Eastern English Channel). Hydrobiologia 518:23-32

Amara R, Lagardère F, Desaunay Y, Marchand JR (2000) Metamorphosis and estuarine colonisation in the common sole, Solea solea (L.): implications for recruitment regulation. Oceanol Acta 23:469-484

> Arslan Z, Secor DH (2005) Analysis of trace transition elements and heavy metals in fish otoliths as tracers of habitat use by American eels in the Hudson River estuary. Estuaries 28:382-393

Baeyens W (1997) Evolution of trace metal concentrations in the Scheldt estuary (1978-1995). A comparison with estuarine and ocean levels. Hydrobiologia 366:157-167

Baeyens W, Leermakers M, De Gieter M, Nguyen HL, Parmentier K, Panutrakul S, Elskens M (2005) Overview of trace metal contamination in the Scheldt estuary and effect of regulatory measures. Hydrobiologia 540:141-154

Beck MW, Heck KL, Able KW, Childers DL and others (2001) The identification, conservation, and management of estuarine and marine nurseries for fish and invertebrates. Bioscience 51:633-641

Beyst B, Mees J, Cattrijsse A (1999) Early postlarval fish in the hyperbenthos of the Dutch Delta (south-west Netherlands). J Mar Biol Assoc UK 79:709-724

Brown JA (2006a) Classification of juvenile flatfishes to estuarine and coastal habitats based on the elemental composition of otoliths. Estuar Coast Shelf Sci 66:594-611

Brown JA (2006b) Using the chemical composition of otoliths to evaluate the nursery role of estuaries for English sole Pleuronectes vetulus populations. Mar Ecol Prog Ser 306: 269-281

Burt GJ, Millner RS (2008) Movements of sole in the southern North Sea and eastern English Channel from tagging studies (1955-2004). Sci Ser Tech Rep 144. Centre for Environment, Fisheries and Aquaculture Science, Lowestoft
Caley MJ, Carr MH, Hixon MA, Hughes TP, Jones GP, Menge BA (1996) Recruitment and the local dynamics of open marine populations. Annu Rev Ecol Syst 27:477-500

Campana SE (1999) Chemistry and composition of fish otoliths: pathways, mechanisms and applications. Mar Ecol Prog Ser 188:263-297

Cowen RK, Sponaugle S (2009) Larval dispersal and marine population connectivity. Annu Rev Mar Sci 1:443-466

> Cowen RK, Lwiza KMM, Sponaugle S, Paris CB, Olson DB (2000) Connectivity of marine populations: open or closed? Science 287:857-859

> De Pontual H, Lagardere F, Troadec H, Batel A, Desaunay Y, Koutsikopoulos C (2000) Otoliths imprinting of sole (Solea solea) from the Bay of Biscay: a tool to discriminate individuals from nursery origins? Oceanol Acta 23: 497-513

De Pontual H, Lagardere F, Amara R, Bohn M, Ogor A (2003) Influence of ontogenetic and environmental changes in the otolith microchemistry of juvenile sole (Solea solea). J Sea Res 50:199-210

> Dellwig O, Bosselmann K, Kölsch S, Hentscher M and others (2007) Sources and fate of manganese in a tidal basin of the German Wadden Sea. J Sea Res 57:1-18

Fogarty MJ, Botsford LW (2007) Population connectivity and spatial management of marine fisheries. Oceanography 20:112-123

Forrester GE, Swearer SE (2002) Trace elements in otoliths indicate the use of open-coast versus bay nursery habitats by juvenile California halibut. Mar Ecol Prog Ser 241: 201-213

> Frank KT, Brickman D (2001) Contemporary management issues confronting fisheries science. J Sea Res 45:173-187

Geffen AJ, Jarvis K, Thorpe JP, Leah RT, Nash RDM (2003) Spatial differences in the trace element concentrations of Irish Sea plaice Pleuronectes platessa and whiting Merlangius merlangus otoliths. J Sea Res 50:247-254

Gillanders BM (2002a) Connectivity between juvenile and adult fish populations: Do adults remain near their recruitment estuaries? Mar Ecol Prog Ser 240:215-223

Gillanders BM (2002b) Temporal and spatial variability in elemental composition of otoliths: implications for determining stock identity and connectivity of populations. Can J Fish Aquat Sci 59:669-679

Gillanders BM, Kingsford MJ (2000) Elemental fingerprints of otoliths of fish may distinguish estuarine 'nursery' habitats. Mar Ecol Prog Ser 201:273-286

Grioche A, Koubbi P, Harlay X, Sautour B (2001) Sole larval distribution (Solea solea) in the eastern English Channel and Southern Bight of the North Sea. J Mar Biol Assoc UK 81:673-678

Hamer PA, Jenkins GP, Coutin P (2006) Barium variation in Pagrus auratus (Sparidae) otoliths: a potential indicator of migration between an embayment and ocean waters in south-eastern Australia. Estuar Coast Shelf Sci 68: $686-702$

> Hamerlynck O, Hostens K, Arellano RV, Mees J, Van Damme PA (1993) The mobile epibenthic fauna of soft bottoms in the Dutch delta (south-west Netherlands): spatial structure. Neth J Aquat Ecol 27:343-358

Hartl DL, Clark AG (2007) Principles of population genetics. Sinauer Associates Publishers, Sunderland, MA

Hedgecock D, Barber PH, Edmands S (2007) Genetic approaches to measuring connectivity. Oceanography 20: 70-79

Hellberg ME, Burton RS, Neigel JE, Palumbi SR (2002) Genetic assessment of connectivity among marine populations. Bull Mar Sci 70:273-290 
Helsel DR, Hirsch RM (2002). Methods for data below the reporting limit. In: Statistical methods in water resources. Techniques of water resources investigations, Book 4, Ch A3. US Geological Survey, Elsevier, Amsterdam, p 357-376

Hostens K (2000) Spatial patterns and seasonality in the epibenthic communities of the Westerschelde (Southern Bight of the North Sea). J Mar Biol Assoc UK 80:27-36

Leakey CDB, Attrill MJ, Jennings S, Fitzsimons MF (2008) Stable isotopes in juvenile marine fishes and their invertebrate prey from the Thames Estuary, UK, and adjacent coastal regions. Estuar Coast Shelf Sci 77:513-522

Leakey CDB, Attrill MJ, Fitzsimons MF (2009) Multi-element otolith chemistry of juvenile sole (Solea solea), whiting (Merlangius merlangus) and European seabass (Dicentrarchus labrax) in the Thames Estuary and adjacent coastal regions. J Sea Res 61:268-274

Limburg KE (1995) Otolith strontium traces environmental history of subyearling American shad Alosa sapidissima. Mar Ecol Prog Ser 119:25-35

Longerich HP, Jackson SE, Gunther D (1996) Laser ablation inductively coupled plasma mass spectrometric transient signal data acquisition and analyte concentration calculation. J Anal At Spectrom 11:899-904

Otto L, Zimmerman JTF, Furnes GK, Mork M, Saetre R, Becker G (1990) Physical oceanography of the North Sea. Neth J Sea Res 26:161-238

Palumbi SR (2004) Marine reserves and ocean neighborhoods: the spatial scale of marine populations and their management. Annu Rev Environ Resour 29:31-68

Patterson WF, Cowan JH, Wilson CA, Chen ZX (2008) Temporal and spatial variability in juvenile red snapper otolith elemental signatures in the northern Gulf of Mexico. Trans Am Fish Soc 137:521-532

Pawson MG (1995) Biogeographical identification of English Channel fish and shellfish stocks. Fish Res Tech Rep 99. Ministry of Agriculture, Fisheries and Food, Directorate of Fisheries Research, Lowestoft.

Rijnsdorp AD, Vanbeek FA, Flatman S, Millner RM, Riley JD, Giret M, Declerck R (1992) Recruitment of sole stocks, Solea solea (L), in the Northeast Atlantic. Neth J Sea Res 29:173-192

Rogers SI, Millner RS, Mead TA (1998) The distribution and abundance of young fish on the east and south coast of England (1981 to 1997). Sci Ser Tech Rep 108. Centre for Environment, Fisheries and Aquaculture Science, Lowestoft

Russell FS (1976) The eggs and planktonic stages of British marine fishes. Academic Press, London

Schaffler JJ, Winkelman DL (2008) Temporal and spatial variability in otolith trace-element signatures of juvenile striped bass from spawning locations in Lake Texoma, Oklahoma-Texas. Trans Am Fish Soc 137:818-829

Secor DH, Rooker JR (2000) Is otolith strontium a useful scalar of life cycles in estuarine fishes? Fish Res 46:359-371

Secor DH, Kerr LA, Cadrin SX (2009) Connectivity effects on productivity, stability, and persistence in a herring metapopulation model. ICES J Mar Sci 66:1726-1732

Editorial responsibility: Hans Heinrich Janssen, Oldendorf/Luhe, Germany
Symonds DJ, Rogers SI (1995) The influence of spawning and nursery grounds on the distribution of sole Solea solea (L.) in the Irish Sea, Bristol Channel and adjacent areas. J Exp Mar Biol Ecol 190:243-261

Thorrold SR, Latkoczy C, Swart PK, Jones CM (2001) Natal homing in a marine fish metapopulation. Science 291: 297-299

Thorrold SR, Jones GP, Hellberg ME, Burton RS and others (2002) Quantifying larval retention and connectivity in marine populations with artificial and natural markers. Bull Mar Sci 70:291-308

Thorrold SR, Zacherl DC, Levin LA (2007) Population connectivity and larval dispersal using geochemical signatures in calcified structures. Oceanography 20:80-89

Thresher RE (1999) Elemental composition of otoliths as a stock delineator in fishes. Fish Res 43:165-204

Van Achterberg E, Ryan CG, Jackson S, Griffin WL (2001). Data reduction software for LA-ICP-MS. In: Sylvester P (ed) Laser-ablation-ICPMS in the earth sciences, principles and applications. Short Course Series Vol 29. Mineralogical Association of Canada, Quebec, p 239-243

van der Land MA (1991) Distribution of flatfish eggs in the 1989 egg surveys in the southeastern North Sea, and mortality of plaice and sole eggs. Neth J Sea Res 27:277-286

> van der Veer HW, Berghahn R, Miller JM, Rijnsdorp AD (2000) Recruitment in flatfish, with special emphasis on North Atlantic species: progress made by the Flatfish Symposia. ICES J Mar Sci 57:202-215

van der Veer HW, Dapper R, Witte JIJ (2001) The nursery function of the intertidal areas in the western Wadden Sea for 0-group sole Solea solea (L.). J Sea Res 45:271-279

> Vasconcelos RP, Reis-Santos P, Tanner S, Fonseca V and others (2007) Discriminating estuarine nurseries for five fish species through otolith elemental fingerprints. Mar Ecol Prog Ser 350:117-126

> Vasconcelos RP, Reis-Santos P, Tanner S, Maia A and others (2008) Evidence of estuarine nursery origin of five coastal fish species along the Portuguese coast through otolith elemental fingerprints. Estuar Coast Shelf Sci 79:317-327

Vinagre C, Amara R, Maia A, Cabral HN (2008a) Latitudinal comparison of spawning season and growth of 0-group sole, Solea solea (L.). Estuar Coast Shelf Sci 78:521-528

Vinagre C, Salgado J, Costa MJ, Cabral HN (2008b) Nursery fidelity, food web interactions and primary sources of nutrition of the juveniles of Solea solea and S. senegalensis in the Tagus estuary (Portugal): a stable isotope approach. Estuar Coast Shelf Sci 76:255-264

> White JW, Ruttenberg BI (2007) Discriminant function analysis in marine ecology: some oversights and their solutions. Mar Ecol Prog Ser 329:301-305

White JW, Standish JD, Thorrold SR, Warner RR (2008) Markov chain Monte Carlo methods for assigning larvae to natal sites using natural geochemical tags. Ecol Appl 18: 1901-1913

Zwolsman JJG (1999). Geochemistry of trace metals in the Scheldt estuary. Geologica Ultrajectina 171. PhD thesis, Utrecht University

Submitted: July 1, 2009; Accepted: November 25, 2009

Proofs received from author(s): February 11, 2010 